INTERNATIONAL JOURNAL OF RESEARCHES IN BIOSCIENCES, AGRICULTURE AND TECHNOLOGY

C VISHWASHANTI MULTIPURPOSE SOCIETY (Global Peace Multipurpose Society) R. No. MH-659/13(N)

www.vmsindia.org

\title{
AVIFAUNAL DIVERSITY OF PADMAPUR AREA, DIST- CHANDRAPUR \\ MAHARASHTRA, INDIA
}

\author{
P. M. Telkhade ${ }^{1}$ and S. H. Jambhule ${ }^{2}$ \\ ${ }^{1}$ Arts, Commerce and Science College Tukum, Chandrapur \\ ${ }^{2}$ Guru Nanak College Ballarpur, Dist. Chandrapur \\ ptelkhade@yahoo.in
}

\begin{abstract}
The enormous diversity of life in itself is of crucial value probably giving greater resilience to ecosystems and cultural values. Birds are unique among vertebrates as they have true ability to fly. They play major role in ecosystems as potential pollinators and scavengers and are rightly called as bio-indicators. Birds are found in various contrasting environments from warm arid zone to cold arid zones. It represents the unique habitat for wild life and avifauna in Central India. A good congregation of avifaunal diversity includes residents, winter visitors and some uncommon birds. In small village ponds are the abode of water birds also gives shelter to good number of avian fauna. The survey of avifauna from this region was undertaken during the period from August 2012 to January 2013. In the present study, total 28 species were recorded. Good congregation of black ibis, black shoulder kite, common coot, Asian Koel and Kingfisher observed and regularly found in and around area.
\end{abstract}

Keywords: Padmapur, avian fauna

\section{Introduction:}

The birds are of great economic importance to man. They play an important role in controlling population of different pests. They are scavengers and pollinating agents and also help's in dispersal of seeds. They provide rich food for mankind and are known to man since ages Chitampally and Bhatkhande, (1993). Ali (1996) laid the foundation of economic ornithology. The birds are very significant component of biodiversity and are the most important indicators of the balanced living systems. The population of birds in a particular ecosystem is depending on the composition of the ecosystem, environmental condition and seasonal variation.

Birds serve as one of the best environmental indicators. Their presence anywhere speaks volumes of the environment as to whether all is well or there is something amiss. The presences of birds also show the biological importance or going technical, the biodiversity significance of that area. Birds are found throughout the world, at approximately all altitudes and in almost every climate. Birds have great efficiency to fly. They are good bioindicators in terms of potential pollinators and scavengers. Population of birds is a sensitive indicator of pollution in both terrestrial and aquatic ecosystem. Many ecologists made their attention to relation of birds with the other communities. The various lake and wetlands in any city serve as a balancing reservoir for sustain native flora and fauna, now a days due to civilization the birds are going to destroyed, which directly affect on their reproduction and nesting (Patil and Tijare, 2012). Birds are essential animal group of an ecosystem and maintain a tropic level. Therefore, detail study on avifauna and their ecology is important to protect them. Earlier researches have studied avifauna in India, Rose (1910), King (1911), Waite (1920), Chintampalli and Bhatkhande (1993), Wadatkar and Kasambe (2002), Yardi, et al., (2004), Kulkarni (2005), Anil Mahabal (2006), Thakor et al., (2010) and Gorghate et al., (2012).

\section{Materials and Methods:}

No specific study on avifaunal status in the urban region of Padmapur area, Chandrapur District has been undertaken, although Chandrapur District holds the Tadoba-Andhari Tiger Reserve which have varied and rich Avifauna. Adjoining area of Tadoba National Park and Andhari wild life sanctuary which is protected area and as a extension to Tadoba Nation Park. Avifauna of Padmapur region of District Chandrapur is unexplored as yet and hence the present survey done. It is $09 \mathrm{~km}$ away from Chandrapur city. It is situated near Super Thermal Power Station, Urjanagar (CTPS).

The birds were observed with the help of binocular and photographed using digital camera Pentax with tele lens, (Mega pixels 3.1 and optical zoom 25x). The survey of avifauna from this region was undertaken during the period from February 2012 to January 2013 in the morning $7.30 \mathrm{AM}$ to $10.30 \mathrm{AM}$ and afternoon 4.30 PM. to 6.30 PM. The identification was done with the help of standard text of Ali (1996) and Ali and Ripley (1983). 


\section{Observation and Result:}

Survey of birds in the area of Padmapur region were studied during February 2012 to January 2013 and tabulated in Table 1.1. In the present study, total 28 species were recorded. Good congregation of black ibis, black shoulder kite, common coot, Asian Koel and Kingfisher observed and regularly found in and around area. The birds observed in the habitat were segregated and documented as 11 residential birds, one resident migratory, 2 occasional and
14 Common birds of the area. According to their feeding habits 4 are Insectivorous birds, 4 are Granivorous birds, 10 are Carnivorous birds, 8 are Omnivorous birds. One Frugivorous, one Fish-eating and one Herbivorous bird were identified. The birds observed in the habitat were segregated and documented as Rare(R), Residential (RS), Resident Migratory (RM), Occasional (O) and Common (C) according to their feeding habits and status of appearance.

Table 1.1: Avifaunal Diversity of Padmapur Area, Chandrapur

\begin{tabular}{|c|c|c|c|}
\hline S. $\mathbf{N}$. & SCIENTIFIC NAME & COMMON NAME & STATUS \\
\hline 1 & Amandava amandava & Red munia & $\mathrm{C}$ \\
\hline 2 & Ardeola grayii & Indian pond heron & $\mathrm{C}$ \\
\hline 3 & Centropus sinensis & Greater Coucal & $\mathrm{O}$ \\
\hline 4 & Coracias benghalensis & Indian roller & $\mathrm{C}$ \\
\hline 5 & Copsychus saularis & Oriental magpie robin & $\mathrm{C}$ \\
\hline 6 & Dicrurus macrocercus & Black drongo & RS \\
\hline 7 & Acridotheres tristis & Common Myna & RS \\
\hline 8 & Accipiter badius & Shikra & $\mathrm{O}$ \\
\hline 9 & Bubulcus ibis & Cattle Egret & $\mathrm{C}$ \\
\hline 10 & Passeridae spp. & Sparrow & RS \\
\hline 11 & Eudynamys scolopaceus & Asian koel & RM \\
\hline 12 & Corvus splendens & House crow & $\mathrm{RS}$ \\
\hline 13 & Merops orientalis & Little Green Bee eater & $\mathrm{RS}$ \\
\hline 14 & Sturnia pagodarum & Brahminy starling & $\mathrm{C}$ \\
\hline 15 & Nectarinia aspasia & Sunbird & $\mathrm{RS}$ \\
\hline 16 & Psittacula krameri & Rose-ringed parakeet & $\mathrm{C}$ \\
\hline 17 & Actitis hypoleucos & Common Sandpiper & $\mathrm{C}$ \\
\hline 18 & Charadrius dubius & Little ringed plover & $\mathrm{R}$ \\
\hline 19 & Ploceus philippinus & Baya weaver & $\mathrm{RS}$ \\
\hline 20 & Orthotomus sutorius & Common Tailor Bird & RS \\
\hline 21 & Turdoides striata & Jungle babbler & $\mathrm{C}$ \\
\hline 22 & Saxicoloides fulicatus & Indian Robin & $\mathrm{C}$ \\
\hline 23 & Pycnonotus cafer & Red vented Bulbul & $\mathrm{C}$ \\
\hline 24 & Streptopelia chinensis & Spotted Dove & $\mathrm{RS}$ \\
\hline 25 & Upupa epops & common Hoopoe & $\mathrm{C}$ \\
\hline 26 & Vanellus indicus & Red wattled Lapwing & $\mathrm{RS}$ \\
\hline 27 & Caprimulgus asiaticus & Common Indian Nightjar & $\mathrm{C}$ \\
\hline 28 & Coturnix coturnix & Common quail & $\mathrm{C}$ \\
\hline
\end{tabular}

\section{Discussion:}

The avifauna of India includes around 1301 species, of which 42 are endemic, 1 has been introduced by humans, and 26 are rare or accidental. Two species have been extirpated in India and 82 species are globally threatened. The Indian Peacock (Pavo cristatus) is the national bird of India. Aquatic birds play an important role in wetland ecosystem because they act as a consumer in trophic levels of such system. They are also considered as an indicator of changes occurring in the aquatic environment.

In the present study, total 28 species were recorded. Good congregation of black ibis, black shoulder kite, common coot, Asian Koel and Kingfisher observed and regularly found in and around area. Kulkarni et al., (2006) reported occurrence of 93 species of birds, belonging to 39 families and 16 orders from
Shikhachi Wadi, Reservoir, Dist. Nanded, Maharashtra. Kumar and Bohara (2002) recorded 103 species of birds belonging to 43 families and 13 orders from Udhuwa Lake (Jharkhand). Osmaston (1922a) studied on Birds of Pachmari. Similarly, Telkhade (2008) recorded total 43 species of birds from TATR Chandrapur. The birds observed in the habitat were segregated and documented as 11 residential birds, one resident migratory, 2 occasional and 14 Common birds of the area. According to their feeding habits 4 are Insectivorous birds, 4 are Granivorous birds, 10 are Carnivorous birds, 8 are Omnivorous birds. One Frugivorous, one Fish-eating and one Herbivorous birds were identified. The birds observed in the habitat were segregated and documented as Rare(R), Residential (RS), Resident Migratory (RM), Occasional (O) and Common (C) according to their feeding habits 
and status of appearance. Kedar and Patil (2005) recorded 60 bird species from Rishi Lake and its surrounding area. Prakash (1999) described 12 species of aquatic birds from Bahadur Sagar (Jhabua) M.P. Yardi et al., (2004) reported 64 species of birds in Salim Ali Lake, Aurangabad.

In the present investigation, total 28 species were recorded. Good congregation of common birds. Birds have their functional role in the ecosystem as potential pollinators and scavengers and are rightly called as bioindicators (James et al., (1999). Birds are the part of the, natural habitat of the Indian subcontinent. In India, there is no off season for birds. Birds have been always fascinated for their ability to fly in air and for their exquisite colouration. They have their functional role in the ecosystem as potential pollinators and scavengers and are rightly called as bioindicators, (Ali and Ripley, 1983).

It is being suggested that the avifauna are important for the ecosystem as they play various roles as scavenger, pollinators and predators of insect pest. The survey is conducted to create the awareness for avifauna biodiversity of Padmapur area for their conservation. It is need of the day to conserve the biodiversity of avifauna of Padmapur Area and Chandrapur District which is a third polluted area of the world.

\section{References:}

Ali, S. (1996). The Book of Indian Birds (11th Ed). Bombay Natural History Society, Bombay, 197.

Ali, S. and S.D. Ripley (1983): A pictorial guide to the birds of the Indian sub-continent. Bombay Natural History Society (BNHS), Mumbai. Pp. 1-354

Anil Mahabal (2006): Aves, Fauna of Tadoba Andhari Tigar Reservoir, Conservation Area Series 25:65-98.

Chintampalli, M. and Bhatkhande (1993): Hansdev's Mrigpakeshi Shastra. M.S. Board of literature and culture, Mumbai.: 1-279.

Gorghat N.D., Khune C.J., Nagpurkar L.P., Parwate B.P. and Raut M.B.(2012):Birds diversity in Siregoan lake District Gondia M.S. India J. Bionano Frontiers Spe. Issu. Vol. 5(2-1) Pp.98-100

Jaman, M.F. and N. Sahreen. (2004) Ecology and breeding biology of Chestnut-tailed starling, Sturnus malabaricus (Gmellin 1789). Ecoprint, 11(1):27-34.

Kedar, G.T. and Patil G.P. (2005): Avifaunal diversity of Rishi Lake, Kranaja (Lad) Maharashtra with reference to food preference and feeding habits. J. Aqua. Biol. 20 (1): 35 38.

King, R C H Moss (1911). "The resident birds of the Saugor and Damoh Districts, Central Provinces". J. Bombay Nat. Hist. Soc. 21 (1): 87103.

http:/ / biodiversitylibrary.org/page/30150758.

Kulkarni, A. K., Kanwate V. S. and Deshpande V. D. (2006): Check list of birds of Shikhachi wadi, Reserovir, dist. Nanded, Maharashtra. J. Aqua.Biol. 21(1): 80 - 85.

Kulkarni, A.N., V.S. Kanwate, V.D. Deshpande (2005): Birds in and around Nanded city, Maharashtra. Zoo's Print Journal, 20(11): Pp. 2076-2078

Kumar, A. and Bohra C. J. (2002): Faunastic composition communities structure population dynamics and ethology of the birds of Udhuwa Lake (Sarithal pargana) and the strategies for the conservation in new millennium. In: Ecology and Conservation of Lakes, Reservoirs and Rivers vol. II. (Ed. A Kumar) ABD Publisher, Jaipur: 411 - 434.

Osmaston, B.B. (1922): Birds of Pachmari. J. Bombay Natural History Society (BNHS), Mumbai. 28: Pp. 453-459

Patil K.G. and Tijare R.V. (2012): Study of feeding habit of avifauna in vicinity of Gorewada lake Nagpur. Bionano frontier Journal (Special issue-9) $112-113$.

Prakash, M.M. (1999): Impact of anthropogenic activites on the aquatic birds population at Bahadur Sagar (Jhabua. M.P.) In: Advances in fish and wild life ecology and biology (ed. B.I. Kaul). Daya Publishing house. New Delhi 2: 174 - 178.

Rose, HA (1910). "Panjab Folklore Notes". Folklore 21 (2): 216-217.

Telkhade P.M. (2008) Hydrobiology and Biodiversity of Tadoba lake Chandrapur. Ph.D. thesis submitted to RTM Nagpur University, Nagpur.

Thakor, F.J.,Acharya C.A.,Bhoi D.K., Prajapati J.R. and Vaidya J.S (2010) A comparative study of avifauna from two reservoirs in kheda District, Gujrat (India), J. Aqua. Biol. 25 (1): 4145.

Wadatkar, J.S. and R. Kasambe (2002) Check list of Birds from Pohara-Malkhed reserve forest. Dist. Amravati, Maharashtra. Zoos print Journal. 17(66): 807-811

Waite,HW (1920). "Birds of different species nesting in company". . Bombay Nat. Hist. Soc. 27 (1): 171.

Yardi, D., Patil S.S. and Auti R.G. (2004): Diversity of Avian Fauna from Salim Ali Lake of Aurangabad. Paper presented in 21st meet of birds lovers of Maharashtra held at Nanded on 3rd, 4th April - 2004. 